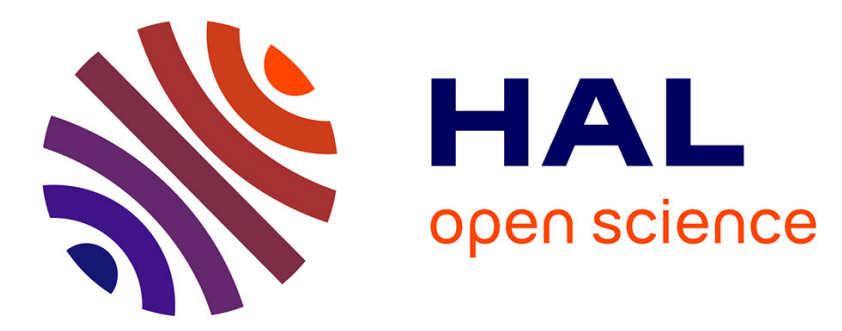

\title{
New species of Karydomys (Rodentia) from the Miocene of Chios Island (Greece) and phylogenetic relationships of this rare democricetodontine genus
}

Raquel López-Antoñanzas, Pablo Peláez-Campomanes, Jérôme Prieto, Fabien Knoll

\section{To cite this version:}

Raquel López-Antoñanzas, Pablo Peláez-Campomanes, Jérôme Prieto, Fabien Knoll. New species of Karydomys (Rodentia) from the Miocene of Chios Island (Greece) and phylogenetic relationships of this rare democricetodontine genus. Papers in Palaeontology, 2019, 5 (1), pp.33 - 45. 10.1002/spp2.1224 . hal-01920708

\section{HAL Id: hal-01920708 https://hal.science/hal-01920708}

Submitted on 29 Dec 2020

HAL is a multi-disciplinary open access archive for the deposit and dissemination of scientific research documents, whether they are published or not. The documents may come from teaching and research institutions in France or abroad, or from public or private research centers.
L'archive ouverte pluridisciplinaire HAL, est destinée au dépôt et à la diffusion de documents scientifiques de niveau recherche, publiés ou non, émanant des établissements d'enseignement et de recherche français ou étrangers, des laboratoires publics ou privés. 


\section{NEW SPECIES OF KARYDOMYS (RODENTIA) FROM THE MIOCENE OF CHIOS ISLAND (GREECE) AND PHYLOGENETIC RELATIONSHIPS OF THIS RARE DEMOCRICETODONTINE GENUS}

\begin{tabular}{|c|c|}
\hline Journal: & Palaeontology \\
\hline Manuscript ID & PALA-11-17-4109-OA.R1 \\
\hline Manuscript Type: & Original Article \\
\hline Date Submitted by the Author: & $\mathrm{n} / \mathrm{a}$ \\
\hline Complete List of Authors: & $\begin{array}{l}\text { López Antoñanzas, Raquel; Institut des Sciences de l'Evolution de } \\
\text { Montpellier, Université Montpellier, Paléontologie; University of Bristol, } \\
\text { School of Earth Sciences } \\
\text { Peláez-Campomanes, Pablo; Museo Nacional de Ciencias Naturales-CSIC, } \\
\text { Departamento de Paleobiología } \\
\text { Prieto, Jêrome ; Ludwig-Maximilians-University } \square \text {, Department of Earth and } \\
\text { Environmental Sciences, Palaeontology and Geobiology, } \\
\text { Knoll, Fabien; ARAID-Fundación Conjunto Paleontológico de Teruel- } \\
\text { Dinópolis; University of Manchester, School of Earth \& Environmental } \\
\text { Sciences }\end{array}$ \\
\hline Key words: & $\begin{array}{l}\text { Mammalia, Cricetidae, }<\text { i }>\text { Karydomys }</ i>\text {, taxonomy, Miocene, cladistics, } \\
\text { Chios }\end{array}$ \\
\hline \multicolumn{2}{|c|}{$\begin{array}{l}\text { Note: The following files were submitted by the author for peer review, but cannot be converted to } \\
\text { PDF. You must view these files (e.g. movies) online. }\end{array}$} \\
\hline S2.tnt & \\
\hline
\end{tabular}

\section{SCHOLARONE ${ }^{m}$ \\ Manuscripts}




\section{NEW SPECIES OF KARYDOMYS (RODENTIA) FROM THE MIOCENE OF CHIOS ISLAND (GREECE) AND PHYLOGENETIC \\ RELATIONSHIPS OF THIS RARE DEMOCRICETODONTINE GENUS}

Raquel López-Antoñanzas ${ }^{1,2}$, Pablo Peláez-Campomanes ${ }^{3}$, Jérôme Prieto ${ }^{4} \&$ Fabien Knoll ${ }^{5,6}$

${ }^{1}$ Institut des Sciences de l'Evolution de Montpellier, Université Montpellier, CNRS, IRD, EPHE, Cc 064; Montpellier, France.

${ }^{2}$ School of Earth Sciences, University of Bristol, Bristol, United Kingdom

${ }^{3}$ Museo Nacional de Ciencias Naturales-CSIC, Madrid, Spain.

${ }^{4}$ Department of Earth and Environmental Sciences, Palaeontology and Geobiology, Ludwig-

Maximilians-University, Munich, Germany

${ }^{4}$ Bayerische Staatssammlung für Paläontologie und Geologie, Munich, Germany

${ }^{5}$ ARAID_Fundación Conjunto Paleontológico de Teruel-Dinópolis/ARAID, Teruel, Spain

${ }^{6}$ School of Earth \& Environmental Sciences, University of Manchester, Manchester, United Kingdom 
*Corresponding author Raquel López-Antoñanzas, Laboratoire de Paléontologie, Institut des Sciences de l'Évolution (UMR-CNRS 5554), Université Montpellier 2, Place Eugène Bataillon, F-34095 MONTPELLIER Cedex 5

E-mail: raquel.lopez-antonanzas@umontpellier.fr

Abstract: Karydomys is a rare and little diversified democricetodontine, of which only six species are currently recognised. This group of rodents is first recorded known sincein the Early Miocene (MN3) in China and spread quickly after to Kazakhstan and Greece (MN 4). Karydomys reached south-western and central Europe by early Middle Miocene times (MN5), where it became extinct shortly thereafter (MN6). New findings from the Miocene of Chios Island (north-eastern Aegean Sea) reveal the presence of a new species of Karydomys in the Keramia Formation. Karydomys $K$. strati sp. nov. is characterized by the presence of a labial spur on the anterolophule, the lack of anterior protolophule on the M1 and by the presence of a double metalophule on the M2. A cladistics analysis involving all the species of Karydomys and some closely related species of Democricetodon and Cricetodon has been earried out. The results-show that Karydomys split early into two different lineages, an "eastern stock", which that includes the central Asian (KarydomysK. debruijni and

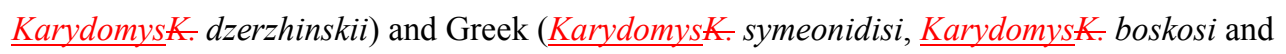
KarydomysK. strati-sp. now.) species ${ }_{2}$ and a "western lineage", which is constituted by the

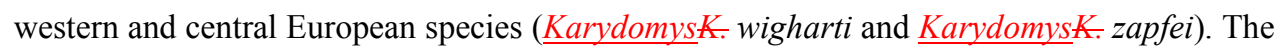
evolutionary stage of Karydomys strati sp. now suggests that the lowermost part of the Keramia Formation, usually attributed to the Middle Miocene, is older than previously thought.

Key words: Mammalia, Cricetidae, Karydomys, phylogenycladistics, taxonomy, Miocene, $\underline{\text { Chios }}$ 


\section{INTRODUCTION}

Asia Minor has been an important area for the exchange of faunas between Europe, Asia and Africa, especially during the early Early Miocene (Roglëgl, 1999; Koufos et al, 2005). At that time, important dispersals from the East occurred through that area, deeply transforming the mammalian composition of Europe (Van der Made 1999; Agustí et al 2001). The faunal changes were particularly important for rodents, since the entrance of "modern" cricetids in Europe at the end of the Early Miocene disrupted the structure of communities at the endo-of the Early Miocene, which, had been till then, were-dominated by eomyids and glirids until then (Daams \& Van der Meulen, 1984; Van der Meulen \& Daams, 1992; Agustí et al 2001). The entrance-appearance of cricetids in Europe was, nevertheless, not the result of an isolated $\underline{\text { single dispersal event migration but instead occurred in a succession of eventsseveral }}$ successive waves, as shown by the timing of arrival of the three main groups of cricetids, the Democricetodontinae, Megacricetodontinae and Cricetodontinae (De Bruijn et al 1992; Theocharopoulos 2000; Van den Hoek Ostende et al 2015; Oliver \& Peláez-Campomanes 2016). In order to fully understand all thesesuch faunal migrationsinterchanges, it is important to improve our knowledge of the fossil record from key areas and develop phylogenetic hypotheses ef about the taxa involved in a robust chronological framework. In this way, the fossil record of small mammals from the early-Early and midelle-Middle Miocene of the north-eastern Aegean island of Chios, at the crossroad between Anatolia and south-eastern Europe, is of key critical importance for the establishment of a more precise biogeographic framework.

In the summer of 2010, two of us (RLA and FK) prospected in Chios Island. After sampling various levels in the Michalos' pit and its surroundings, they were able to locate two layers with Miocene vertebrates (López-Antoñanzas \& Knoll, 2011). The higher fossiliferous horizon was an arenaceous stratum that yielded only a cranial fragment of a 


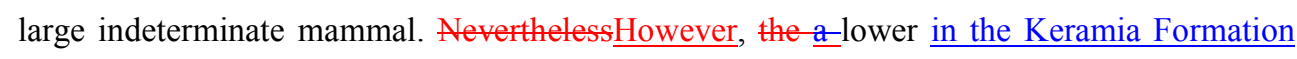
one was a a thin argillaceous lens in the Keramia Formation, that produced a diverse vertebrate fauna after screen-washing and sorting, which motivated a return to the site in the summer of 2012 and the exploitation of the lens to near its-exhaustion. Altogether, over two metric tons of rock were processed, obtaining as a result nearly 200 teeth of small mammals. In fact, even though remains of large mammals (comprising a phalange of an indeterminate ruminant, a possible tooth fragment of Cainotherium and another of Sanitherium) and reptilian jaw and osteoderm fragments were retrieved from this new spot, rodents and, to a lesser extent, lagomorphs and insectivores are best represented by far. Preliminary identification of the lagomorphs suggests the presence of Albertona. The insectivore record consists of galericines. Rodents include a wide range of taxa belonging to cricetids, glirids, sciurids and ctenodactylids. Among them, cricetids are the most abundant, in particular species belonging to genera usually present in the eastern Mediterranean region during the early Miocene, such as Cricetodon, Megacricetodon and Democricetodon, but remains of the rare-unusual democricetodontine genus Karydomys were also found.

Karydomys is a rare and little diversified democricetodontine, which shows a discontinuous record, geographically as well as chronologically. Its oldest record (Karydomys debruijni) comes from the early Miocene (MN3) of northern Xinjian (China) (Maridet et al., 2011). This taxonThe genus may have rapidly expanded its range westward, as its presence is attested shortly later in the early Miocene (MN4) of eastern Kazakhstan (Karydomys dzerzhinskii) (Kordikova and De Bruijn, 2001) and Greece (Karydomys boskosi and Karydomys symeonidisi) (Theocharopoulos, 2000). Some undescribed findings of Karydomys from the early Miocene (MN 4) of western Anatolia (Ünay \& Goktas, 1999; Kaya et al., 2007) indicate that this area may well have been on a route between central Asia and Greece. Karydomys may have reached south-western (Karydomys zapfei) (Mein \& Freudentahl 1981) 


\section{GEOLOGICAL SETTING}

\section{Stratigraphical context}

Chios Island is situated in the north-eastern part of the Aegean Sea. The continental Tertiary Cenozoic sediments of Chios are located mainly in the southeastern part of the island, unconformably overlying Mesozoic strata (Fig. 1). The Neogene deposits have been subdivided by Besenecker (1973) into four lithostratigraphical units, which are from bottom to top: the Thymiana Formation (Early Miocene), Zyfia Formation (Early_-_Middle Miocene), Keramia Formation (Middle Miocene) and Nenita Formation (Middle Miocene__Pliocene).

The Keramia Formation is about $120 \mathrm{~m}$ thick (Kondopolous et al., 2011). It consists mainly of layers of green-reddish clay and silt with less important layers of green sandstones intercalated (Besenecker, 1973). The green and reddish colours are characteristic of this formation and make it easily recognizable in the field (Besenecker, 1973). Besides, the 
sediments of the Keramia Formation are clearly delimited by a light "Tuff-horizon" below, en the base and by the overlying white limestones of the Nenita Formation on the top (Besenecker, 1973).

Kondopoulou et al. (1993) conducted a magnetostratigraphical study in a 46_m-thick section of the Keramia Formation in the Michalos' pit area that included the three fossiliferous localities THA, THB and THC. The long reversal dominating the section was tentatively correlated to-either with chron $\mathrm{C} 5 \mathrm{Br}$ or chron $\mathrm{C} 5 \mathrm{Cr}$ based on the biochronological age given-then suggested by the-mammals-found. -Later on, Kondopoulou et al. (2011) provided some-supplementary magnetostratigraphical data resulting from the sampling of the almost complete Keramia Formation in the Michalos section (about $120 \mathrm{~m}$ thickness), also including approximately $10 \mathrm{~m}$ of the Zayfa Formation at the bottom-of the section. Thus, they include presented information about the lower and uppermost parts of the section that was not considered in Kondopoulou et al. (1993). Even if the detailed magnetostratigraphical resultsstudy areis still pending publication (Kondopoulou et al. 2011), theirTheir preliminary interpretation of their-results could beseem to be in agreement eorrelating with a correlation of the section to-with the interval including chron-C5Dr to E5bnC5Bn (Hilgen et al., 2012, fig. 29.9).

\section{Palaeontological background and biochronology}

All of the vertebrate specimens yielded so far by the Miocene layers of Chios (at least in modern history) come from the exposure of the Keramia Formation in or close to the brickyard quarry known as "Michalos", which is situated SSE of the village of Thymiana, about $8 \mathrm{~km}$ from Chios city. The first finding of vertebrate remains from Michalos' pit was made in 1924 by the geologist GeorgalasGeorgaleas, but Paraskevaidis $(1940,1955)$ was the first to publish on the Miocene vertebrate fauna from Chios (macromammals, Sanitherium and others, but also evidence of tortoises). Additional, but more cursory, observations on 
similar vertebrate remains (macromammal — particularly sanitheriid and bovid— but also chelonian fragments) from the Neogene of the vicinity of Thymiana were published by Kreatsas (1963). Palaeontological field-works in the Michalos area that were conducted in 1967 and 1968 in the framework of a Germano-Hellenic project led-contributed to improvez significantly improvement improved of our the understanding of the mammalian fauna from the Keramia Formation (see Melentis \& Tobien, 1967, 1968, Tobien, 1968, 1969, 1977, 1980, Rothausen, 1977, Lehmann \& Tobien, 1995). In total, nine fossiliferous layers were recognized at the end of 60's, Thy 1-9, which were and-described by Rothausen (1977). Most of the material collected then was fragmentary remains of bovids and giraffids, but a nearly complete skull of Gomphotherium angustidens was also discovered (and is still remembered locally!). Micromammals were also found, but were never described in detail and their

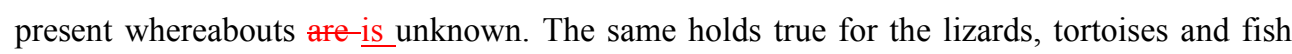
remains also foundretrieved-along. Complementary studies on the vertebrate faunas from Chios arose from Helleno-French field campaigns in 1991 and 1993 (Kondopoulou et al., 1993; Koufos et al., 1995; Bonis et al., 1997a, 1997b, 1998; López-Antoñanzas et al., 2005). In addition to the nine fossiliferous levels described by Rothausen (1973), three new levels were found in the 90 's by the Hellenic-French teamon this occasion, "Thymiana A" (THA), "Thymiana B" (THB) and "Thymiana C" (THC) (Kondoupulou et al., 1993). Besides a few interesting macromammalian remains (mostly of sanitheriid and bovid affinities), some of them well preserved, these fieldworks resulted in the eollection building up of a rich micromammal faunacollection, which is yet to be studied in its entirety.

Our main fossiliferous layer is situated on the coast, about 340 meters SSW from the main brick building. It does not correspond to any of the localities previously sampled. The stratigraphical position of the new layer suggests it may be coeval with the most basal 


\section{MATERIAL AND METHODS}

Remains of micromammals were obtained by screen washing almost 2 tons of sediment with a mesh light of $0.5 \mathrm{~mm}$. First, second and third lower molars are designated as $\mathrm{m} 1, \mathrm{~m} 2$ and $\mathrm{m} 3$, and first, second and third upper molars as M1, M2 and M3, respectively. The 
terminology used in the tooth descriptions follows those of Freudenthal et al. (1994) and López-Antoñanzas et al. (2010). Measurements of the occlusal surface of the teeth (maximum length $[\mathrm{L}]$ and maximum width [W]) were obtained with a Nikon digital counter CM-6S measuring device, following the method of van de Weerd (1976) (Table 1). All measurements are given in millimetres. The teeth of the species of Karydomys described in this work were compared with all the all-known species belonging to this genus. Scans and SEMs of the teeth of the specimens have been taken with a CT-SCAN Nikon XT H-160 and a Scanning Electron Microscope FEI QUANTA 200.

All the species of Karydomys known to date were included in the ingroup. These are:

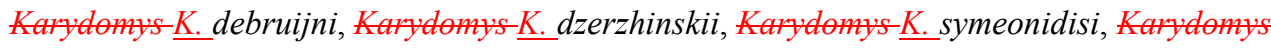

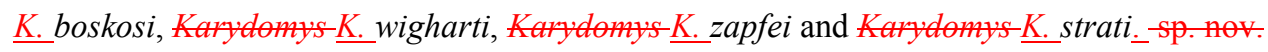
from Chios. In addition, a selection of closely related non-congeneric species were added to the ingroup so as to test the monophyly of the genus Karydomys and to clear up its phylogenetic relationships with species currently attributed to Democricetodon, from which Karydomys may have evolved, and Cricetodon. These are Democricetodon anatolicus,

Democricetodon-D.doukasi, Democricetodon-D. gracilis, Democricetodon-D. franconicus, Democricetodon-D. mutilus, Cricetodon versteegi, Ericetodon-C. tobieni, Ericetodon-C. kasapligili, Ericeton-C.aliveriensis, Ericeton-C.trallesensis, Ericetodon-C.orientalis, Ericeton-C. meini, Ericetodon-C. engesseri, Ericeton-C. hungaricus, Ericetodon $\underline{C}$. bolligeri. Eucricetodon wangae, a primitive Cricetidaecricetid rodent, was selected as outgroup. A total of 32 phylogenetically informative characters (mainly of dental morphology) have been coded (see appendix S1 S1). 19 characters are binary, whereas 13 are multistate. The data matrix (archived in the Dryad Digital Data Repository: LópezAntoñanzas et al. 2018) see appendix S2) was built using Mesquite 23. $6-04$ (Maddison and Maddison 2009) and the analysis was run in TNT (Goloboff et al. 2008) with the "traditional 
Type species. Karydomys symeonidisi Theocharopoulos, 2000

Karydomys strati sp. nov.

LSID.urn:1sid:zoobank.org:act:0958B82F-9788-4DE3-94EF-6287172E1103

Figs 2-3

Derivatio nominis. From Stratus, łatinized-latinised form of Stratos_(Greek: $\Sigma \tau \rho \alpha ́ \tau o c)$, genitive. In honour of Stratos Asmanis in recognition of his warm-hearted hospitality during our work in the Michalos pit. 


\section{Holotype. Thy UM Thy 0-30, a left M2. This and the paratype specimens are housed in the palaeontological collections of the University of Montpellier (Montpellier, France).}

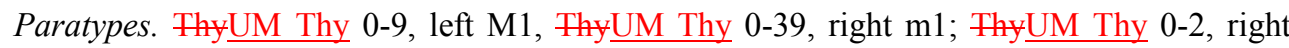

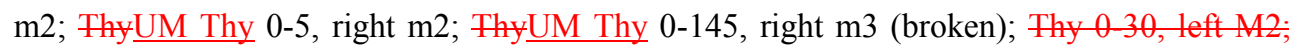
Thy UM Thy 0-48 left M2; Thy UM Thy 0-54, left M2 (broken).

Type tocalityhorizon and locality. Thymiana 0. Lowermost part of the Keramia Formation, SSE of the village of Thymiana, about $8 \mathrm{~km}$ from Chios city (Greece).

Age. late Early Miocene (MN4).

Diagnosis. Species of Karydomys characterized by having a backward paracone spur and long and narrow mesolophs on the M1 and M2, having labial spur of the anterolophule and lacking anterior protolophule and metalophule on the M1 but having double protolophules and metalophules on the M2; lower molars with ectomesolophid and long and narrow mesolophids.

Karydomys strati differs from Karydomys $\underline{\text {-arydomys }}$ debruijni in lacking the posterior metalophulid on the $\mathrm{m} 1$, in having a well-developed ectomesolophid on some $\mathrm{m} 2$, a strong posterior spur of the paracone on the M1 and M2 and a double metalophule on the M2 (whereas it is either anteriorly connected or absent in Karydomys Karydomys: debruijni). It differs from Karydomys dzerzhinskii in lacking the anterior protolophule on the M1, in having the anterior and posterior protolophule unequally developed and in showing a double metalophule on the M2 (in Karydomys Karydomys-dzerhinskii the single metalophule is usually anteriorly located). It can be distinguished from Karydomys symeonidisi in lacking the anterior protolophule on the M1, which is present in most of the M1 of Karydomys:symeonidisi, and in having a double metalophule on the M2. It is unlike Karydomys boskosi in being larger, lacking a posterior ridge of the metaconid and having a strong metalophulid and longer and narrower mesolophid on the m1. It differs from Karydomys wigharti in being 


\section{Description}

$\mathrm{m} 1 \mathrm{The} \mathrm{m} 1$ has a small and single oval anteroconid. Both labial and lingual anterolophids are distinct. The labial anterolophid is of medium length and it does not reach the base of the protoconid, whereas the lingual one is short and encloses a rounded anterosinusid. The anterior metalophulid that connects the metaconid with the anteroconid is well-developed, whereas the posterior one is absent. The long and narrow mesolophid reaches the lingual side of the tooth, where it forms a mesostylid. The ectomesolophid is long and narrow. The entoconid is located anteriorly to the hypoconid and the hypolophid is close to the mesolophid. The posterolophid is long and reaches the posterior side of the entoconid lingually, closing the posterosinusid. The roots of this tooth are not preserved.

m2 Two lower second molars, of which one is in-very well preserved and the other is damaged, have been found. The occlusal outline of these teeth is rectangular. Both show well-developed labial and lingual anterolophids. The labial anterolophid is longer than the lingual one. The metalophulid connects to the anteroconid. The anterolophulid is very short. The mesolophid is nearly transverse, either long and narrow (Thy UM Thy 0-5) or but it can

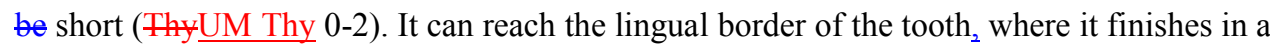
mesostylid (Thy UM Thy 0-5). The metaconid and the mesolophid are connected by a longitudinal ${ }_{2}$ and thin crest. The ectomesolophid is long (Thy UM Thy $0-5$ ) or absent (as-in 


\section{M1 The anterocone of the A-single first upper molar found has been found. The anterocone-is} slightly divided. The lingual anteroloph is a very thin crest that runs to meet the anterior side of the protocone, enclosing the protosinus. The strong anterolophule connects the protocone to the middle part of the anterocone. This tooth shows a distinct labial spur on the anterolophule. The anterosinus is labially closed by a low ridge, which runs from the labial side of the anterocone to the anterior part of the paracone. This tooth has no anterior protolophule (protolophule I) and the posterior protolophule (protolophule II) connects to the entoloph well-posteriorly to the protocone. The protocone and the entoloph are firmly connected. The tooth shows a short but very distinct backward paracone spur. The mesoloph is long and narrow, reaching the labial border of the tooth. The sinus is closed by a ridge that connects the anterolingual side of the hypocone to the base of the protocone. The 


\section{Cladistic analysis}

The cladistic analysis including all species of Karydomys as well as relevant species currently placed in the genera Democricetodon and Cricetodon yielded a single most parsimonious tree with a length of 86 and a relatively high degree of homoplasy $(\mathrm{CI}=0.512 ; \mathrm{RI}=0.806)$. Our results (Fig. 5) evidence two main lineages thatgroups separated from one another-at the most

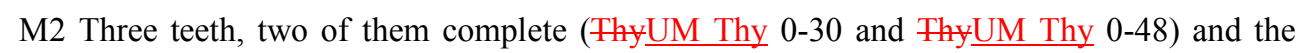
other one damaged (Thy UM Thy 0-54), have been found. The teeth show well-developed labial and lingual anterolophs. The labial anteroloph is connected to the base of the paracone, enclosing a narrow anterosinus, whereas the lingual one reaches the base of the protocone enclosing the protosinus. The protolophule is double, but its degree of development varies from one specimen to another. Specimen Thy UM Thy 0-30 shows the anterior protolophule slightly interrupted and weaker than the posterior one. ThyUM Thy 0-48 has the anterior protolophule strong, whereas the posterior one is weaker and interrupted. Thy $\underline{\mathrm{UM} \text { Thy }}$ 0-54 has both anterior and posterior protolophules complete. All specimens have a long and narrow mesoloph that ends with a mesostyle at the labial border of the teeth. The backward paracone spur is short but strong and reaches the mesostyle in two out of the four specimens available. The teeth have a double metalophule with the posterior one stronger than the anterior one. Both the anterior and the posterior metalophules are nearly longitudinal and they can even form an additional longitudinal crest on their own (specimen Thy Thy 0-30). The posteroloph is short and connects to the posterior metalophule. It nearly reaches the metacone, enclosing a small posterosinus. The roots of these teeth are not preserved.

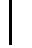

metalophule is short and joins with the posteroloph. This latter connects to the metacone, enclosing a small posterosinus. The roots of this tooth are not preserved. 


\section{DISCUSSION}

The examination of the new rodent remains from Chios has allowed to evidence the presence ofrevealed eight molars (Figs 2-3) belonging to a middle sized Karydomys (Fig. 4) but different from the molars in all theof any species of this genus known so far. Karydomys strati sp. nov. is morphologically close to the two known species from Karydia. However, it shows some important differences, particularly concerning the protolophule and the metalophule on the M1 and M2 and the degree of development of the mesolophids, which prevent to consider it as belonging to either of them. The presence of a double metalophule on the M2 (Fig. 6) may suggest that the new species from Chios could be, in fact, slightly older than Karydomys symeonidisi and Karydomys boskosi, in which the anterior metalophule is lost not only on the M1 but also on the M2. The absence, on the M1 of Karydomys strati, of the anterior protolophule, which is present in Karydomys symeonidisi-, and the presence of a spur on the anterolophule on the M1, a primitive character absent in Karydomys

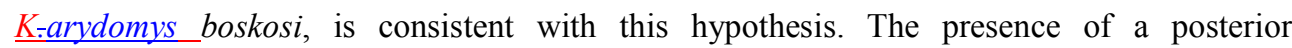
metalophule on the M2 of Karydomys strati suggest that it is more evolved than Karydomys 


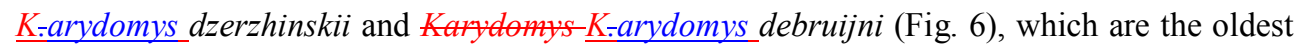
species of Karydomys. In addition, Karydomys from Chios is distinct from Middle Miocene

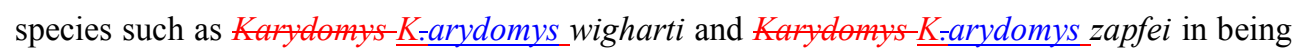
noticeably smaller, in lacking the anterior protolophule on the M1 (present in Karydomys $\underline{K}$. wigharti), in having a well-developed posterior paracone spur on the M1 and M2 as well as in the presence of the ectomesolophid on the m1 (Fig. 6).

The genus Karydomys was erected by Theocharopoulos (2000) on the basis of some characters such as the presence of a small posterosinus and well-developed ectolophs on the first two upper molars (in some of the taxa), the reduction of the size of the third molars and the presence of a small, blade-like anteroconid situated very close to the protoconid and the metaconid on the first lower molar. However, as pointed out by Maridet et al. (2011), some of these characters, such as the presence of a small posterosinus, resulting from a posterior position of the metalophule ${ }_{2}$ as well as the development of the ectolophs (posterior paracone spur in the present work), are not present in all the species of the genus. Therefore, Maridet et al. (2011) suggested that the diagnosis of the genus had to be revised when more material

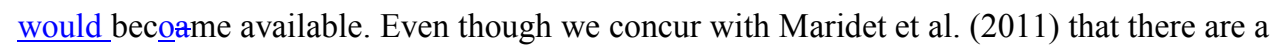
number of issues related to the diagnosis of the genus Karydomys, we are inclined to maintain this taxon in its current specific-composition as the species of Karydomys form a monophyletic grouping in our analysis. The clade Karydomys shares indeed one exclusive synapomorphy:- which is to have a slightly divided or "crest-like" anterocone on the M1 (3 $(0 \rightarrow 1))$. In fact, the M1 of Karydomys are ALSOcharacterized by a wider and flater anterocone more independent from the anteroloph than those ofin Democricetodon, in which it is a well-defined cusp that may fuse with the anteroloph bywith wear. The presence of a short lingual anterolophid $(23(0 \rightarrow 1))$ on the $\mathrm{m} 1$ supports also the clade, but this is shown by someoccurs in some species of Democricetodon as well (e.g. Democricetodon 
D-emocricetodon anatolicus of our ingroup). A very interesting synapomorphy is found int the connection of the anterior metalophulid anterior on the $\mathrm{m} 1$. Thus, it This crest joins the $\underline{a}$ distinct anterolophulid in Democricetodon $(24(0 \rightarrow 1))_{2}$ whereas itbut connects directly

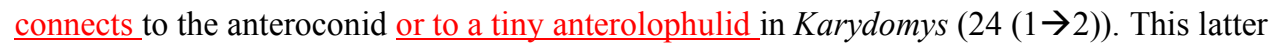
synapomorphy feature is also-shared by the members of the genus Cricetodon.

According to our results Karydomys split early into two different lineages. One constituted by the central Asiatic-Asian (Karydomys debruijni and Karydomys dzerzhinskii) and Greek species-(Karydomys symeonidisi, Karydomys boskosi and Karydomys strati-sp. nov.) species, which we term herein the "eastern lineage", and the other one formed by the species from Germany and France (Karydomys K-arydomys wigharti and Karydomys

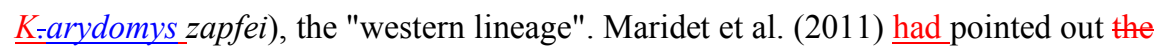
morphological differences between the the species of Karydomys, those-from western and central Europe (France and Germany) and south-eastern Europe (Greece)_-on the one side, and those the species from central Asia (Kazakhstan and north-western China) on the other, on the other side. The latter were considered the least derived particularly on the basis of the morphology of the M2. Our results show a basal position of the two central Asiatic-Asian species of Karydomys (Karydomys K-arydomys debruijni and Karydomys K-arydomys dzerzhinskii) with respect to the Greek ones, but not regarding the western European species Karydomys $\underline{K}$-arydomys wigharti and Karydomys $\underline{K}$-arydomys zapfei, which belong to a separate lineage. The cladogram shows sister group relationships between Karydomys dzerzhinski from Kazaksthan and the clade composed by the three Greek species (Karydomys

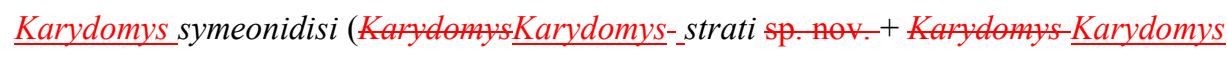
boskosi)). These results are consistent with the suggestion of Kordikova and de Bruijn (2001) about a close relationship between Karydomys Karydomys dzerzhinski and Karydomys Karydomys symeonidisi, with the former a plausible ancestor of the later. Our results also 
show that Karydomys wigharti is sister species of Karydomys-Karydomys zapfei. Mörs and Kalthoff (2004) emphasized the morphological affinities between these two speciesthem. Some synapomorphies of the species of Karydomys for central Asia and south-eastern Europe allow for differentiating them from the taxa from western and central Europe. In particular, the presence of a short but distinct backward paracone spur on the M1 $(8(0 \rightarrow 1)$, a derived character state, and the presence of a well-developed ectomesolophid on the m1 $(27(0 \rightarrow 1))$, another derived character state, are eharacters-features that are usually lacking on the two western and central European species Karydomys wigharti and Karydomys zapfei. However, these are not clear-cut discriminators as the-several M1 of Karydomys debruijini show a backward paracone spur that varies from more or less short to absent altogether, and the ectomesolophid is equally variable in the $\underline{i t s}$ degree of development on the $\mathrm{m} 1$ of $\underline{\underline{i n}}$ Karydomys wigharti. Besides morphology, the western and central European species are also larger than the other species of Karydomys and, indeed, Democricetodon. The grouping of the Greek species of Karydomys is supported by stout cusps $(2(0 \rightarrow 1))$, which is a parallelism with the western and central European species. The Greek species also show a welldeveloped backward paracone spur on the M2 $(15((0 \rightarrow 1))$, which is a character state incipient in Karydomys dzerzhinski.

The diagnostic characters provided by Theocharopoulos (2000) to differentiate Karydomys from Democricetodon are not valid for all taxaspecies. On one side, the presence of a small anteroconid, which was used to discriminate the two genera, is a

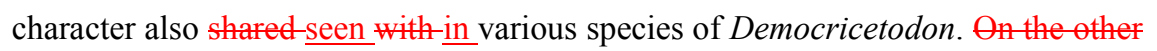
sideFurther, the alleged presence of better developed ectolophs in Karydomys than in Democricetodon_, is actually lacking in the two western and central European members of Karydomys (Karydomys-Karydomys wigharti and Karydomys K-arydomys zapfei) but present in some species of Democricetodon (e.g. Democricetodon-D-emocricetodon anatolicus), 


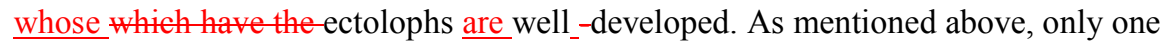
exclusive synapomophy backs up the clade Karydomys, which is a slightly divided or "crestlike" anterocone on the M1. We have reservations about the adequacy of such a unique character to justify the legitimacy of the genus Karydomys. However, the differences between Democricetodon and Karydomys regarding the nature of the connection of the anterior metalophulid anterior should also be taken into account. The species currently attributed to Karydomys may as well be seen as pertaining to Democricetodon, as derived members of the genus. At this point, however, we refrain for formally synonymising Karydomys with Democricetodon given the incomplete nature of our ingroup. Should a future, more comprehensive, phylogenetic analysis of the species of Democricetodon and Karydomys yield a pattern of results in line with our own (i.e. Democricetodon forming a paraphyletic array of species relative to a Karydomys clade) then the merits of the recognition of the genus Karydomys will have to be seriously questioned. In any case, the close relationships between the genera Karydomys and Democricetodon suspected by Theocharopoulos (2000) are confirmed.

The teeth of the taxa belonging to Cricetodon are morphologically quite different from those of Democricetodon and Karydomys. Our cladogram clearly supports the monophyly of Cricetodon. The species of Cricetodon included in the ingroup share some exclusive synapomorphies. They have the anterocone strongly divided $(3(0 \rightarrow 1))$ and a short mesoloph $(9(0 \rightarrow 1))$ on the M1. Their $\mathrm{m} 1$ are characterized by having a large anteroconid $(22(0 \rightarrow 1))$ and by usually lacking the lingual anterolophid $(23(0 \rightarrow 1))$. With respect to the $\mathrm{m} 2$, the less derived members of the group they have a weak lingual anterolophid in the less derived members of the group $(28(0 \rightarrow 1))$, which completely disappear in the more evolved members-representatives of the clade $(28(1 \rightarrow 2))$. Their $\mathrm{m} 3$ show a more or less circular protosinusid $(31(0 \rightarrow 1))$ instead of having it retracted and directed forward as is the case in 


\section{CONCLUSION}

The new species Karydomys strati sp. nov. has been erected in this work to accommodate new-remains of Karydomys recently recovered from the Miocene of Chios. According to our phylogenetic analysis, the genus Karydomys split early into two different lineages, an "eastern stock" that includes the central Asian and Greek species and a "western lineage", which is constituted by the western and central European species of the genus. Karydomys strati belongs to the so-called "eastern lineage"stock". This quite-relatively large--sized democricetodontine rodent is characterized by having a labial spur on the anterolophule and the lacking of the anterior protolophule on the M1 and as well as by the presence of a double metalophule on the M2. This latter character suggests that Karydomys strati is more evolved than Karydomys $\underline{K}$-arydomys dzerzhinskii and Karydomys $\underline{K}$-arydomys debruijni, which are are-both lackingdevoid of the posterior metalophule, but less evolved than the Greek species Karydomys - K. symeonidisi and Karydomys $\underline{K}$. boskosi, which areare-both lacking the anterior metalophule.

The presence of Karydomys is of interest from a biostratigraphical point of view. The Keramia Formation has been usually given a Middle Miocene age. However, the evolutionary stage of the new species of Karydomys that it yields suggests that the its stratigraphical level it comes from could be, in fact, slightly older than those from which Karydomys $\underline{\text { Karydomys }}$ symeonidisi and Karydemys - -arydomys boskosi were collected (MN4). The lowermost part 
of the Keramia Formation may, therefore, well-be late Early Miocene in age (MN4), which would be in accordance with the latest published magnetostratigraphical data of the area.

Acknowledgements. We sincerely thank I. Antoñanzas-Asso, E. López-Antoñanzas and J. A. Molina-Anadón for their help during the field work and/or the sorting of sediment.

Permission to conduct field research in the Island of Chios carried out by R. L-A. and F. K. was granted by the Greek Institute of Geology and Mineral Exploration (Acharnae).

Permission to prospect the private Michalos brickyard quarry was granted-ensured by Stratos Asmanis, who made our kindly suppert us during the-sojourns in Chios most enjoyable. $\mathrm{T}_{\star}$. Mörs (Swedish Museum of Natural History, Stockholm, Sweden), S. Thomas (The Palaeontological Association, Durham, United Kingdom) and an anonymous reviewer enhanced this work through careful, critical reading. M. Furió, A. García, C. Paradela, and L. Tormo (Museo nacional de Ciencias naturales-CSIC, Madrid) nicely were kind enough to take took the $\mu$ CT scan images and SEMs.

This work is dedicated to the memory of my beloved father, M-anuel López Gálvez, who will live forever in our hearts.

\section{DATA ARCHIVING STATEMENT}

This published work and the nomenclatural act it contains, have been registered in

ZooBank: http://zoobank.org/References/81D56B1D-2B00-4FCB-90D7-2C1D15EA0B7B

Data for this study are available in the Dryad Digital Repository:

http://datadryad.org/review?doi=doi:10.5061/dryad.m086rm8 Jplease note that the data for this paper are not yet published and this temporary link should not be shared without the express permission of the author] 


\section{REFERENCES}

AGUSTÍ, J., CABRERA, L., GARCÉS, M., KRIJGSMAN, W., OMS, O., and PARÉS, J.M., 2001. A calibrated mammal scale for the Neogene of Western Europe. State of the art. Earth-Science Reviews, 52, 247-260.

BESENECKER, H. 1973. Neogen und Quartär der Insel Chios (Ägäis). Unpublished PhD thesis, Universität Berlin, Berlin, 184 pp.

BONIS, L. de and KOUFOS, G.D. 1999. The Miocene large mammal succession in Greece; pp. 205-237, in Agustí, J., Rook, L., and Andrews, P. (eds), The Evolution of Neogene terrestrial ecosystems in Europe. Cambridge university press, Cambridge.

BONIS, L. de, KOUFOS, G.D. and SEN, S. 1998. Ruminants (Bovidae and Tragulidae) from the middle Miocene (MN5) of the island of Chios, Aegean sea (Greece). Neues Jahrbuch für Geologie und Paläontologie, Abhandlungen, 210, 399-420.

BONIS, L. DE, KOUFOS, G.D. and SEN, S. 1997a. The Sanitheres (Mammalia, Suoidea) from the Middle Miocene of Chios island, Aegean Sea, Greece. Revue de Paléobiologie, 16, 259-270.

BONIS, L. DE, KOUFOS, G.D. and SEN, S. 1997B. A giraffid from the middle Miocene of the island of Chios, Greece. Palaeontology, 40, 121-123.

BOWDICH, T. E. 1821. An analysis of the natural classifications of Mammalia for the use of students and travellers. J. Smith, Paris, $115 \mathrm{pp}$.

BREMER, K., 1994. Branch support and tree stability. Cladistics, 10, 295-304.

BRUIJN, H. DE, DAAMS, R., DAXNER-HÖCK, G., FAHLBUSCH, V., GINSBURG, L., * -MEIN, P. and MORALES, J. 1992. Report of the RCMNS working group on fossil mammals, Reisenburg 1990. Newsletters on Stratigraphy, 26, 65-118. 
BRUIJN, H. DE, FAHLBUSCH, V., SARAC, G., and ÜNAY, E. 1993. Early Miocene Rodent Faunas from the Eastern Mediterranean Area .3. The Genera Deperetomys and Critetodon with a Discussion of the Evolutionary History of the Cricetodontini. Proceedings of the Koninklijke Nederlandse Akademie Van Wetenschappen, Ser. B, 96, $151-216$.

DAAMS, R., and VAN DER MEULEN, A. J. 1984. Paleoenvironmental and paleoclimatic interpretation of micromammal faunal successions in the upper Oligocene and Miocene of north central Spain. Paléobiologie continentale, 14, 241-257.

FISCHER VON WALDHEIM, G. 1817. Adversaria zoologica. Mémoires de la Société Impériale des Naturalistes de Moscou, 5, 357-471.

FREUDENTHAL, M., HUGUENEY, M. and MOISSENET E. 1994. The genus Pseudocricetodon (Cricetidae, Mammalia) in the Upper Oligocene of the province of Teruel (Spain). Scripta Geologica, 104, 57-114.

GOLOBOFF, P. and FARRIS, J., 2001. Methods for quick consensus estimation. Cladistics, $17,26-34$.

GOLOBOFF, P., FARRIS, J. and NIXON, K.C., 2008. TNT, a free program for phylogenetic analysis. Cladistics, 24, 774-786.

HILGEN, F.J., LOURENS, L.J. and VAN DAM, J.A. 2012. The Neogene Period; pp. 923- * 978, in Gradstein, F.M., Ogg, J. G., Schmitz, M.D., and Ogg, G.M. (eds), Geological Time Scale 2012. Elsevier, Oxford.

KAYA, O., ÜNAY, E., GÖKTAS, F. and SARAÇ, G. 2007. Early Miocene stratigraphy of * Central West Anatolia, Turkey: implications for the tectonic evolution of the Eastern Aegean area. Geological Journal, $\mathbf{4 2}, 85$ 
KORDIKOVA, E. G. and BRUIJN, H. de 2001. Early Miocene rodents from the Aktau Mountains (south-eastern Kazakhstan). Senckenbergiana Lethaea, 81, 391-405.

KONDOPOUlOU, D., DE BONIS, L., KOUFOS, G. D. and SEN, S. (1993): Palaeomagnetic data and biostratigraphy of the middle Miocene vertebrate locality of Thymiana (Chios island, Greece). Proceedings of the second congress of the Geophysical Society of Greece, 2, 626-635.

KONDOPOUlOU, D., SEN, S., AIDONA, E., HINSBERGEN, D. and KOUFOS, G. 2011. Rotation history of Chios Island, Greece since the Middle Miocene. Journal of Geodynamics, 51, 327-338.

KOUFOS, G. D., BONIS, L. de. and SEN, S. 1995. Lophocyon paraskevaidisi, a new viverrid (Carnivora, Mammalia) from the Middle Miocene of Chios Island, Greece. Geobios, 28, 511-523.

KOUFOS, G.D., KOSTOPOULOS, D.S., and VLACHOU, T.D. 2005. Neogene/Quaternary mammalian migrations in Eastern Mediterranean. Belgian Journal of Zoology 135, 181190.

KOUFOS, G. D. 2006. The Neogene mammal localities of Greece: faunas, chronology and biostratigraphy. Hellenic Journal of Geosciences, 41, 183-214.

KREATRAS, K. 1963. The Neogene of the SE region of Chios (Greece). Bulletin of the Geological Society of Greece, 4-5, 92__107. [in Greek, English summary].

LEHMANN, U. and TOBIEN, H. 1995. Artiodactyle fossilien (Mammalia) aus dem Miozän von Thymiana, Chios. Annales de Géologie des Pays Helléniques, 36, 403-414.

LINDSAY, E. H. 1987. Cricetid rodents of Lower Siwalik deposits, Potwar Plateau, Pakistan and Miocene mammal dispersal events. Proceedings of the VIIIth RCMNS 
LÓPEZ-ANTOÑANZAS, R., SEN, S. and KOUFOS G. D. 2005. Presence of a ctenodactylid (Rodentia) in the Keramaria Formation (Middle Miocene) of Chios Island (Greece). Geobios, 38, 113-126.

LÓPEZ-ANTOÑANZAS, R., PELÁEZ-CAMPOMANES, P., ÁlVAREZ-SIERRA, M. A. and GARCÍA-PAREDES, I. 2010. New species of Hispanomys (Rodentia, Cricetidae) from the Upper Miocene of Batallones (Madrid, Spain). Zoological Journal of the Linnean Society, 160, 725-747.

LÓPEZ-ANTOÑANZAS, R. and KNOLL, F. 2011. New insights into the vertebrate fauna from the Miocene of Chios (Greece). Journal of Vertebrate Paleontology, 31, 146-147.

MADDISON, W.P. and MADDISON, D.R., 2009. Mesquite: A Modular System for Evolutionary Analysis, ver. 2.6. Mesquite Project, Vancouver.

MADE, J. VAN DER. 1999. Intercontinental relationship Europe-Africa and the Indian Subcontinent. 457-472. In RÖSSNER, G. H.; and HEISSIG, K. (eds). The Miocene land mammals of Europe. Dr. Friedrich Pfeil, München, 483 pp.

MARIDET, O., WU, W. Y., YE, J., BI, S. D., NI, X. J. and MENG, J. 2011. Early Miocene cricetids (Rodentia) from the Junggar basin (Xinjiang, China) and their biochronological implications. Geobios, 44, 445-459.

MEIN, P. 1989. Updating of MN zones. 73-90. In LINDSAY, E. H., FAHLBUSCH, V., and MEIN, P. (eds). European Neogene mammal chronology. Plenum Press, New York, 628 pp.

MEIN, P. and FREUDENTHAL, M. 1981. Les Cricetidae (Mammalia, Rodentia) du Néogène Moyen de Vieux-Collonges Partie 2 Cricetodontinae incertae sedis, Melissiodontinae, Platacanthomyinae, et Anomalomyidae. Scripta Geologica, 60, 1-11.

MELENTIS, J. K. and TOBIEN, H. 1967. Paläontologische Ausgrabungen auf der Insel Chios (eine vorläufige Mitteilung). Praktika tes Akademias Athenon, 42, 147-152. 
MELENTIS, J. K. and TOBIEN, H. 1968. Paläontologische Ausgrabungen auf der Insel

Chios (eine vorläufige Mitteilung). Annales de Géologie des Pays Helléniques, 19, 647652.

MEULEN VAN DER, A.J.VAN DER, and DAAMS, R., 1992. Evolution of Early__Middle Miocene rodent faunas in relation to long-term palaeoenvironmental changes. Palaeogeography, Palaeoclimatology, Palaeoecology, 93, 227-_253.

MÖRS, T. and KALTHOFF, D. 2004. A new species of Karydomys (Rodentia, Mammalia) and a systematic re-evaluation of this rare Eurasian Miocene hamster. Palaeontology, 47, $1387-1405$.

OLIVER, A. and PELÁEZ-CAMPOMANES, P. 2016. Early Miocene evolution of the rodent Megacricetodon in Europe and its palaeobiogeographical implications. Acta

Palaeontologica Polonica, 61, 211-219.

PARASKEVAIDIS, I. 1940. Eine obermiocäne fauna von Chios. Neues Jahrbuch für Mineralogie, Geologie und Paläontologie, 83, 363-442.

PRIETO, J. 2012. The rare cricetid rodent Karydomys Theocharopoulos, 2000 in the fissure filling Petersbuch 6 (Middle Miocene, Germany). Zitteliana, 52, 67-70.

PRIETO, J. 2013. First record of Karydomys (Rodentia, Mammalia) from the German part of the North Alpine Foreland Basin. Swiss Journal of Geosciences, 106, 303-307.

RÖGL, F. 1999. Mediterranean and Paratethys. Facts and hypotheses of an Oligocene to Miocene paleogeography (short overview). Geologica carpathica, 50, 339-349.

ROTHAUSEN, K. 1977. Die mittelmiozänen Wirbeltierfundstellen südlich Thymiana (Insel Chios, Ägäis, Griechenland). 2. Teil: Geologie: Die Fundstellen und ihre Abfolge. Annales de Géologie des Pays Helléniques, 28, 495-515.

STEININGER, F. F., BERNOR, R. L. and FAHLBUSCH, V. 1989. European Neogene marine/continental chronologic correlations.15-46. In LINDSAY, E. H., FAHLBUSCH, V., and MEIN, P. (eds). European Neogene mammal chronology. Plenum Press, New York, $628 \mathrm{pp}$. 
THEOCHAROPOULOS, K. D. 2000. Late Oligocene-_Middle Miocene Democricetodon, Spanocricetodon and Karydomys n. gen. from the Eastern Mediterranean area. Gaia, 8, 192.

TOBIEN, H. 1968. Pälaeontologische-Paläontologische Ausgrabungen nach jungtertiären Wirbeltieren auf der Insel Chios (Griechenland) und bei Maragheh (NW-Iran). Jahrbuch der Vereinigung "Freunde der Üniversitüt Universität Mainz", 51-58.

TOBIEN, H.- 1969. Wirbeltiergrabungen im Miozän der Insel Chios (Ägäis). Praktika tes Akademias Athenon, 43, 151-157.

TOBIEN, H. 1977. Die mittelmiozänen Wirbeltierfundstellen südlich Thymiana (Insel Chios, Ägäis, Griechenland). Annales de Géologie des Pays Helléniques, 28, 489-494.

TOBIEN, H. 1980. A note on the skull and mandible of a new choerolophodont mastodon (Proboscidea, Mammalia) from the middle Miocene of Chios (Aegean Sea, Greece). 299307. In JACOBS, L. L. (ed.). Aspects of Vertebrate History: essays in honor of Edwin Harris Colbert. Museum of Northern Arizona Press, Flagstaff, 412 pp.

ÜNAY, E. and GÖKTAŞ, F. 1999. Late Early Miocene and Quaternary small mammals in the surroundings of Söke (Aydm): Preliminary results. Geological Bulletin of Turkey, 42, 99-114.

VAN DEN HOEK OSTENDE, L. W., MAYDA, S., OLIVER, A., MADERN, A., HERNÁNDEZ-BALLARÍN, V., and PELÁEZ-CAMPOMANES，P. 2015. Aliveri revisited, a biogeographical appraisal of the early Miocene mammals from the eastern Mediterranean. Palaeobiodiversity and Palaeoenvironments, 95, 271-284.

VAN DE WEERD, A. 1976. Rodent fauna of the Mio-Pliocene continental sediments of the Teruel-Alfambra region, Spain. Utrecht Micropaleontological Bulletins, Special Publication, 2, 1-185. 
1-Size of the M1: (0) small, 1.2-1.8 mm; (1) medium size, 1.8-2.6 mm; (2) large $>2.6 \mathrm{~mm}$

2-Cusps: (0) slender; (1) stout

$\underline{\mathrm{M} 1}$

3-Anterocone: (0) single; (1) slightly divided or crest like; (2) divided

4-Anterolabial cingulum: (0) present; (1) absent

5-Labial spur of the anterocone: (0) absent; (1) present

6-Labial spur on the anterolophule: (0) absent; (1) present

7-Anterior protolophule: (0) absent; (1) present

$\underline{\text { 8-Backward paracone spur: (0) very weak or absent; (1) short but distinct; (2) long }}$

9-Mesoloph: (0) long; (1) short or medium length; (2) absent

10-Metalophule: (0) anterior; (1) posterior

11-Posteroloph: (0) long; (1) continues beyond the metalophule; (2) does not continue beyond $\underline{\text { the metaloph; (3) absent }}$

12- Roots: (0) three; (1) four

$\underline{\mathrm{M} 2}$

13-Anterior protolophule: (0) complete; (1) weak; (2) absent

14-Posterior protolophule: (0) absent; (1) weak; (2) complete

$\underline{\text { 15-Backward paracone spur: (0) absent; (1) present }}$

16-Mesoloph: (0) long; (1) short or medium sized; (2) absent

17-Metaloph: (0) anterior; (1) double; (2) posterior

18-Roots: (0) three; (1) four

$\underline{\mathrm{M}}$ 


\section{9-Relative size: (0) large, LM1/LM3 <1.7; (1) small, LM1/LM3 >1.7}

20-Neoentoloph: (0) absent; (1) present

21-Mesoloph: (0) absent; (1) short; (2) long

$\underline{\mathrm{m} 1}$

22-Anteroconid: (0) small; (1) large

23-Lingual anterolophid: (0) well developed; (1) short (2) absent

24- Anterior metalophulid: (0) absent; (1) more or less transversely directed and connected to the anterolophulid (2) very anteriorly directed and generally connected to the anteroconid

25-Posterior metalophulid: (0) present; (1) mostly absent

26-Mesolophid: (0) absent; (1) short to medium length (length $<1 / 3$ of the distance between ectolophid and lingual border); (2) long to medium length

27-Ectomesolophid: (0) very weak or absent; (1) present $\underline{\mathrm{m} 2}$

28-Lingual anterolophid: (0) developed; (1) very weak or not developed 29-Posterior metalophulid: (0) present; (1) weak or absent

30-Mesolophid: (0) short (length $<1 / 3$ of the distance between ectolophid and lingual border); (1) $\underline{\text { long }}$ $\underline{\mathrm{m} 3}$

31-Protosinusid: (0) retracted and directed forward; (1) circular 32-Mesolophid: (0) present; (1) absent 


\section{Figure captions}

TEXT-FIG. 1. Simplified geological map of Chios Island (redrawn from Kondopoulou et al. 1993 ) and location of the fossiliferous site Thy 0.

TEXT-FIG. 2. Lower cheek teeth of Karydomys strati sp. nov. A-D. SEM photographs of the occlusal surface of the teeth. A, Thy UM Thy 0-39, right $\mathrm{m} 1$. B, Thy UM Thy 0-5, right m2. C, Thy UM Thy 0-2, right m2. D, Thy UM Thy 0-145, right m3. E-H. CT-Sean-scan images of Thy UM Thy 0-39, right $\mathrm{m} 1$; E, occlusal view; F, lingual view; G, labial view; $H$,

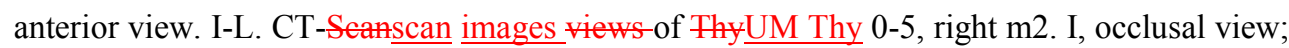
J, lingual view; K, labial view; L, anterior view. M-P. CT-Scanscan images views of Thy $\underline{\mathrm{UM}}$ Thy $0-2$, right $\mathrm{m} 2$; $\mathrm{M}$, occlusal view; $\mathrm{N}$, lingual view; $\mathrm{O}$, labial view; $\mathrm{P}$, anterior view. Q-S.

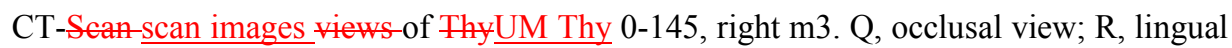
view; S, labial view. The scale bar equals 1 mm for the SEM images (CT-Sean-scan images have been approximately scaled).

TEXT-FIG. 3. Upper cheek teeth of Karydomys strati sp. nov. A-D. SEM photographs of the occlusal surface of the teeth. A, Thy UM Thy 0-9, left M1; B, Thy UM Thy 0-30, left M2;

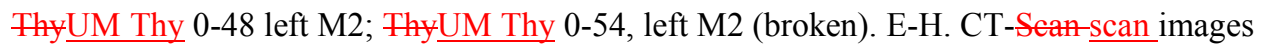
of Thy UM Thy 0-9, left M1; E, occlusal view; F, lingual view; G, labial view; H, anterior

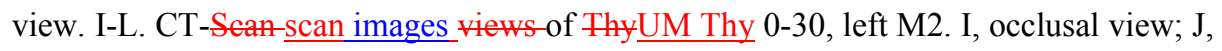
lingual view; K, labial view; L, anterior view. M-P. CT-Scan-scan views-images of Thy $\underline{\mathrm{UM}}$ Thy 0-48 left M2; M, occlusal view; N, lingual view; O, labial view; P, anterior view. Q-S. CT-Sean-scan images views-of Thy $\underline{\mathrm{UM} \text { Thy }}$ 0-54, left M2. Q, occlusal view; R, labial view; 
TEXT-FIG. 5. Cladogram showing the relationships among all known species of Karydomys as well as selected enes ofDemocricetodon and Cricetodon and the phylogenetic position of Karydomys strati sp. nov. (data matrix in Dryad Digital Data Repository: López-Antoñanzas et al. 2018Supplementary File 2). Nodes show Bremer and Relative Bremer Indices-are showed at the appropriate nodes.

TEXT-FIG. 6. Evolutionary stage of various species of Karydomys with some important structures signaled. A-C, K- $\underline{\text { arydomys } d z e r z h i n s k i i ~(t a k e n ~ f r o m ~ K o r d i k o v a ~ \& ~ d e ~ B r u i j n, ~}$ 2001); D-F, Karydomys strati sp. nov.; G-I, K-arydomys wigharti (taken from Mörs \& Kalthoff, 2004). The scale is not included as the morphology only is considered. 


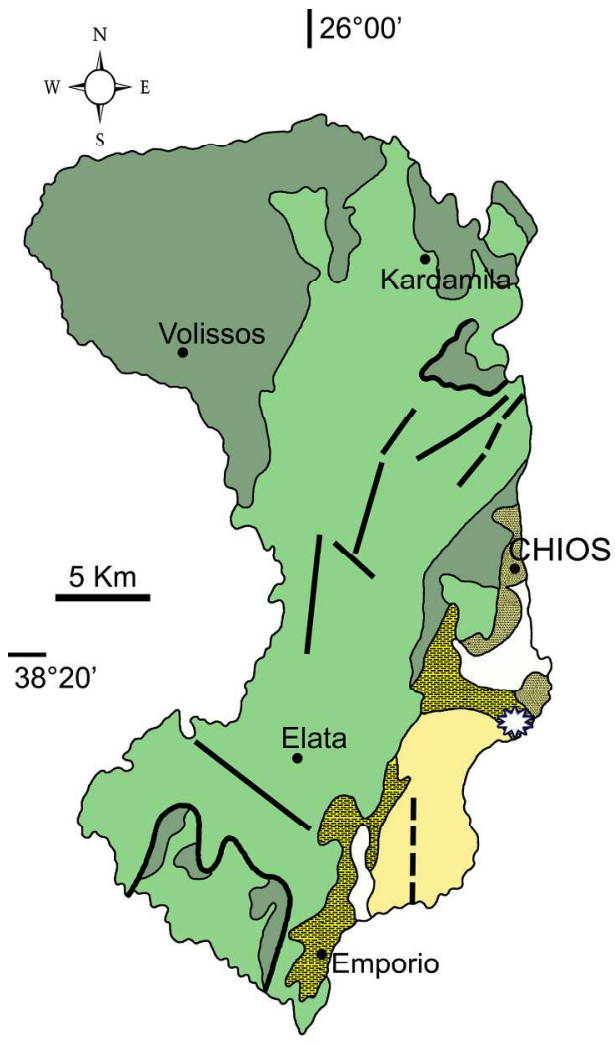

$\square$ Holocene

Fresh-water limestone with intercalations of marls and clays Upper Miocene - Pliocene

Green sands, gravels and reddish-violet silts Middle Miocene

Brownish to reddish ferruginous sandstones

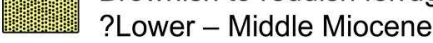

Dolomites and limestones

Mesozoic

Clastic rocks, mainly greywackes with intercalations of conglomerates, shales and limestone lenses Palaeozoic

Faults

$\sum^{m} w^{3}$ Fossiliferous site

Simplified geological map of Chios Island (redrawn from Kondopoulou et al. 1993) and location of the fossiliferous site Thy 0 .

$209 \times 175 \mathrm{~mm}(300 \times 300 \mathrm{DPI})$ 

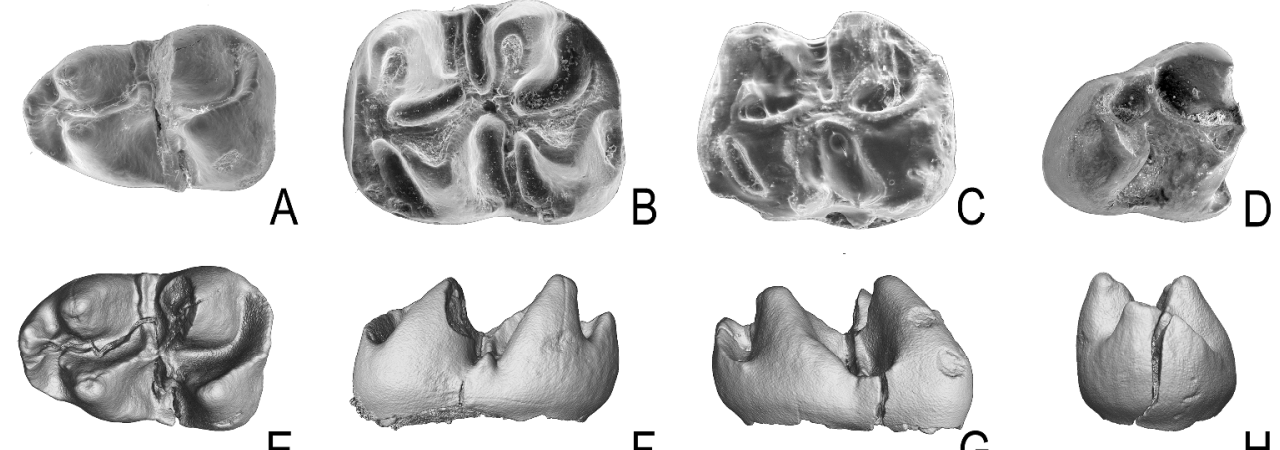

$\mathrm{F}$
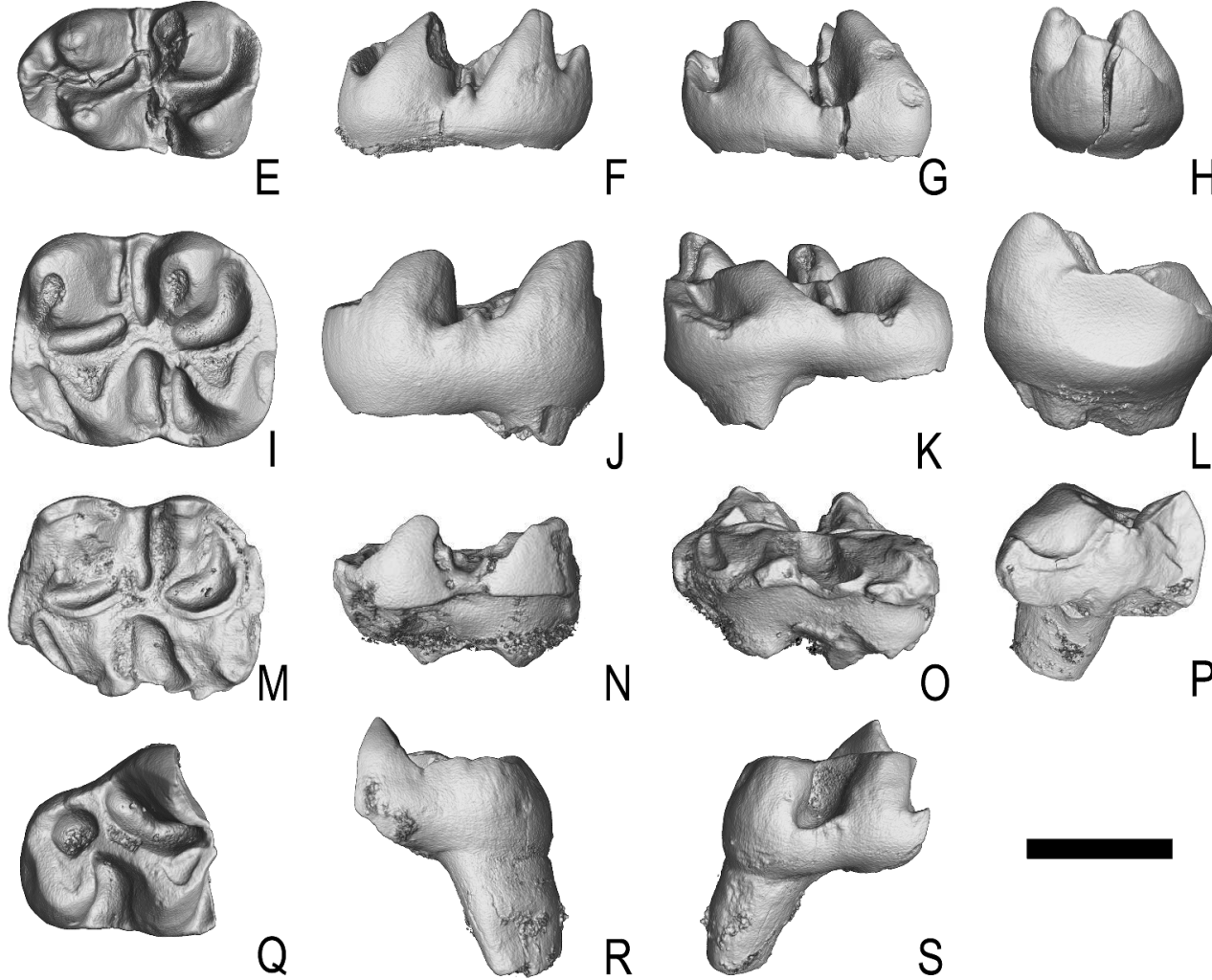

N
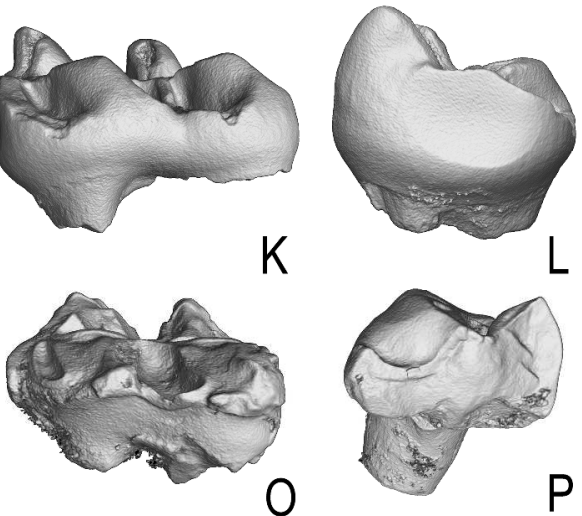

Q

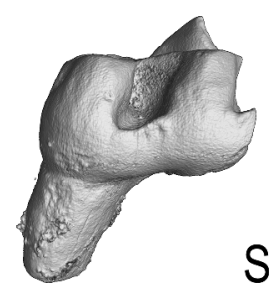

Lower cheek teeth of Karydomys strati sp. nov. A-D. SEM photographs of the occlusal surface of the teeth. A, UM Thy 0-39, right $\mathrm{m} 1$. B, UM Thy 0-5, right $\mathrm{m} 2$. C, UM Thy 0-2, right $\mathrm{m} 2$. D, UM Thy 0-145, right m3. E$\mathrm{H}$. CT-scan images of UM Thy $0-39$, right $\mathrm{m} 1$; $\mathrm{E}$, occlusal view; $\mathrm{F}$, lingual view; $\mathrm{G}$, labial view; $\mathrm{H}$, anterior view. I-L. CT-scan images of UM Thy 0-5, right m2. I, occlusal view; J, lingual view; K, labial view; L, anterior view. M-P. CT-scan images of UM Thy $0-2$, right $\mathrm{m} 2 ; \mathrm{M}$, occlusal view; $\mathrm{N}$, lingual view; $\mathrm{O}$, labial view; P, anterior view. Q-S. CT-scan images of UM Thy $0-145$, right $\mathrm{m3}$. Q, occlusal view; R, lingual view; $\mathrm{S}$ labial view. The scale bar equals $1 \mathrm{~mm}$ for the SEM images (CT-scan images have been approximately scaled). 

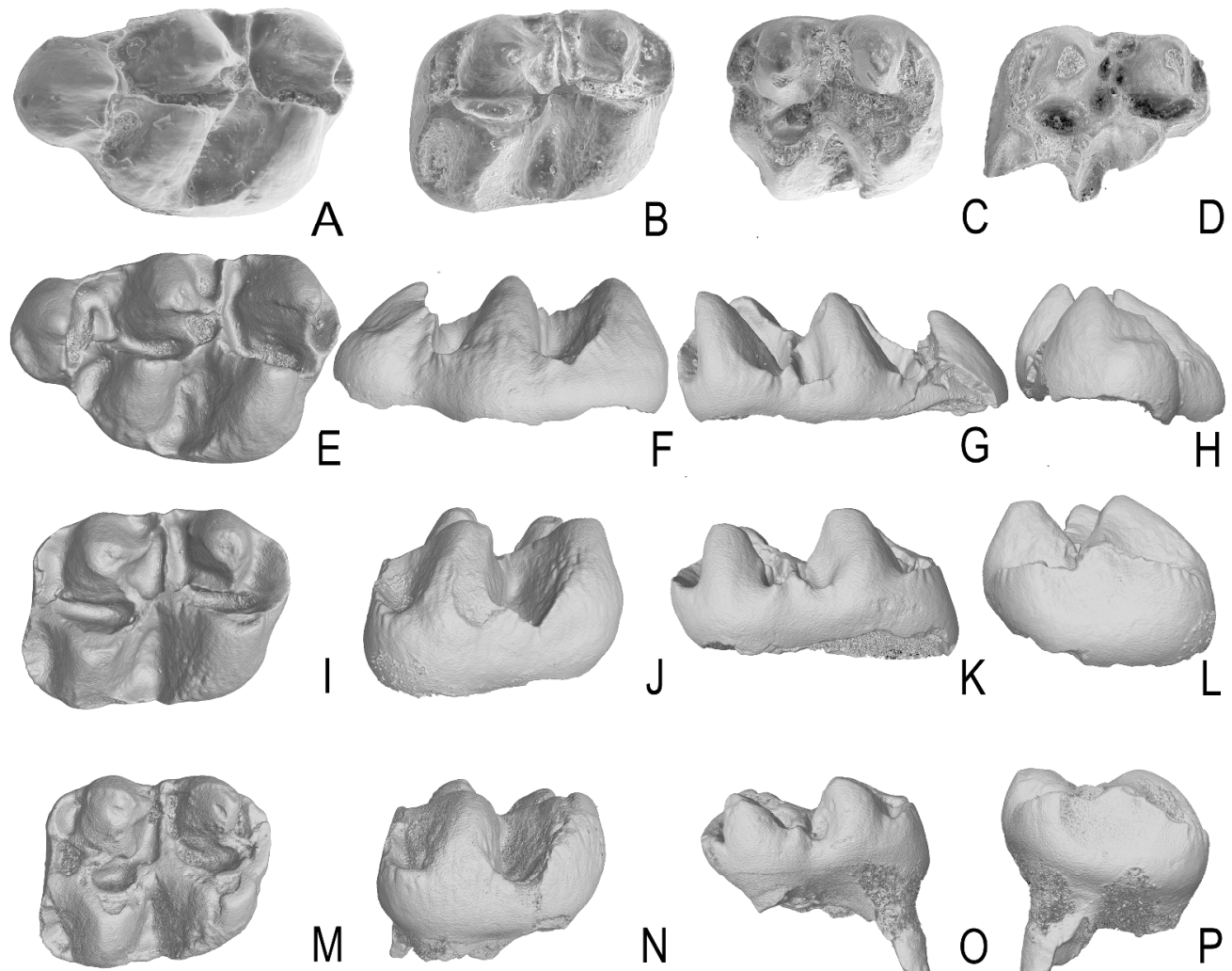

N
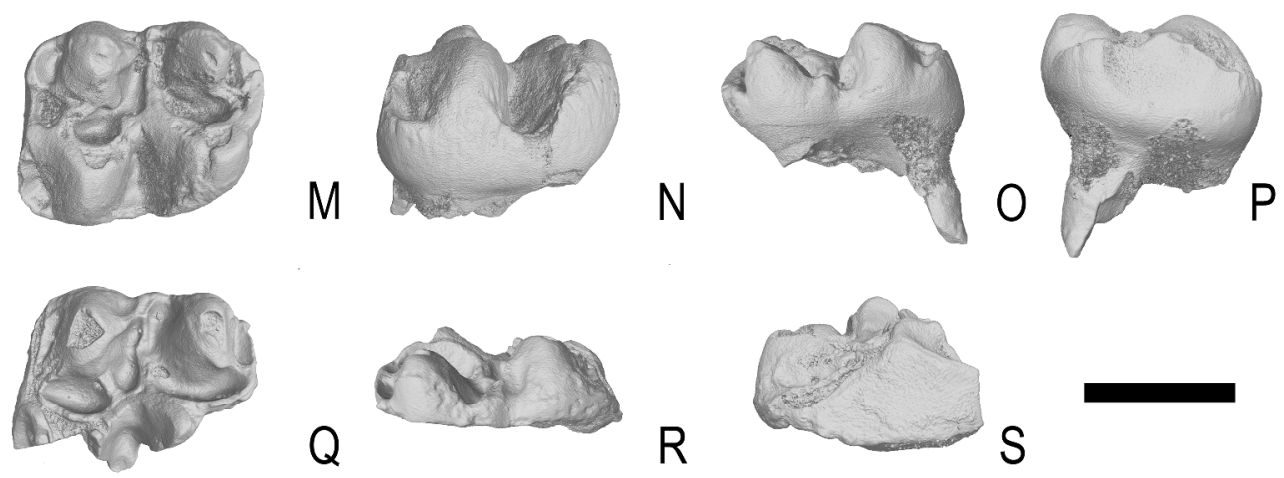

R

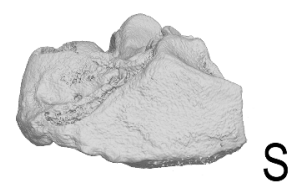

Upper cheek teeth of Karydomys strati sp. nov. A-D. SEM photographs of the occlusal surface of the teeth. A, UM Thy 0-9, left M1; B, UM Thy 0-30, left M2; UM Thy 0-48 left M2; UM Thy 0-54, left M2 (broken). E-H. CT-scan images of UM Thy $0-9$, left M1; E, occlusal view; $F$, lingual view; $G$, labial view; $H$, anterior view. IL. CT-scan images of UM Thy 0-30, left M2. I, occlusal view; J, lingual view; $K$, labial view; $L$, anterior view. M-P. CT-scan images of UM Thy 0-48 left M2; M, occlusal view; N, lingual view; O, labial view; $P$, anterior view. Q-S. CT-scan images of UM Thy 0-54, left M2. Q, occlusal view; R, labial view; S, anterior view. The scale bar equals $1 \mathrm{~mm}$ for the SEM images (CT-scan images have been approximately scaled). 

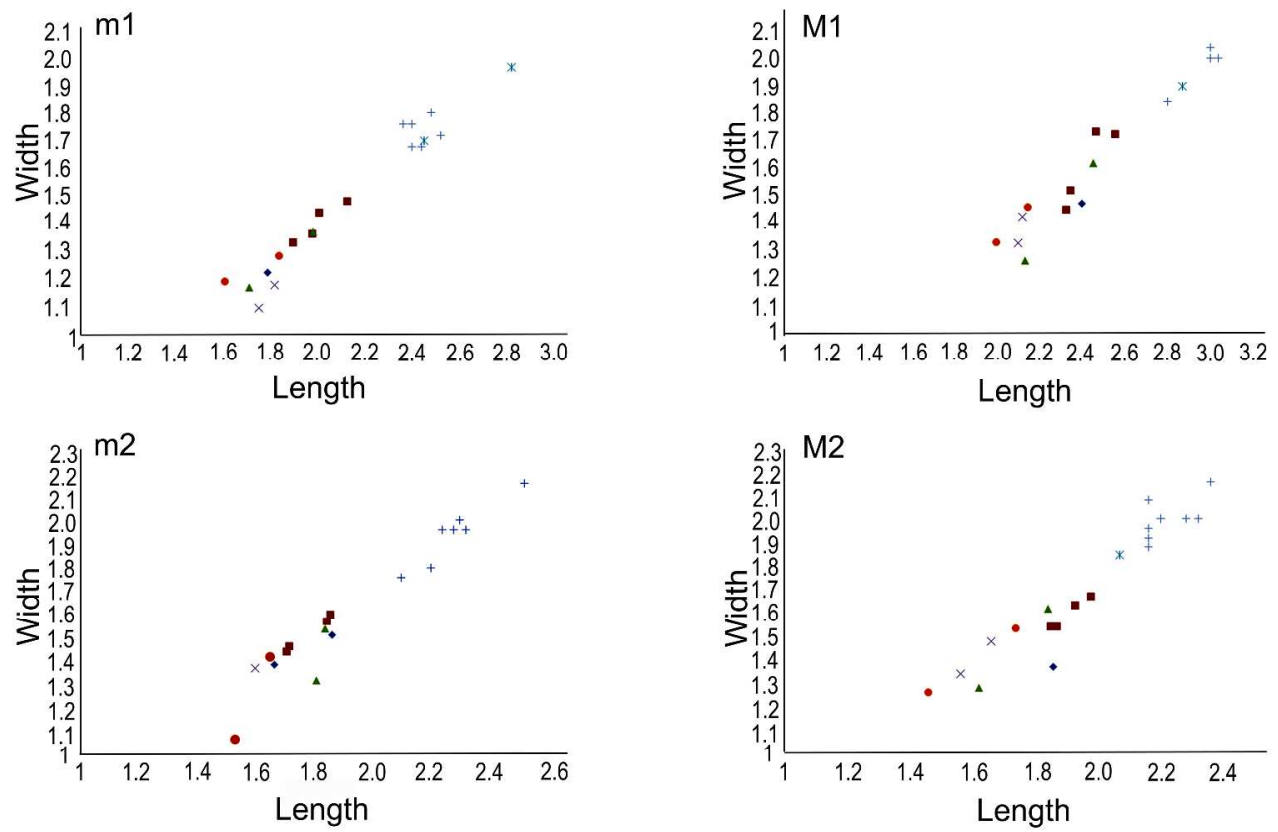

-. Karydomys strati sp. nov.

- Karydomys symeonidisi

- Karydomys debruijni

$\times$ Karydomys boskosi

* Karydomys zapfei

+.Karydomys wigharti

^Karydomys dezerhinskii

Length/width scatter diagram of the two first upper and lower molars of the different species belonging to the genus Karydomys. 
Cladogram showing the relationships among all known species of Karydomys as well as selected Democricetodon and Cricetodon and the phylogenetic position of Karydomys strati sp. nov. (matrix in Supplementary File 2). Nodes show Bremer and Relative Bremer Indices.

$$
203 \times 276 \mathrm{~mm}(600 \times 600 \mathrm{DPI})
$$



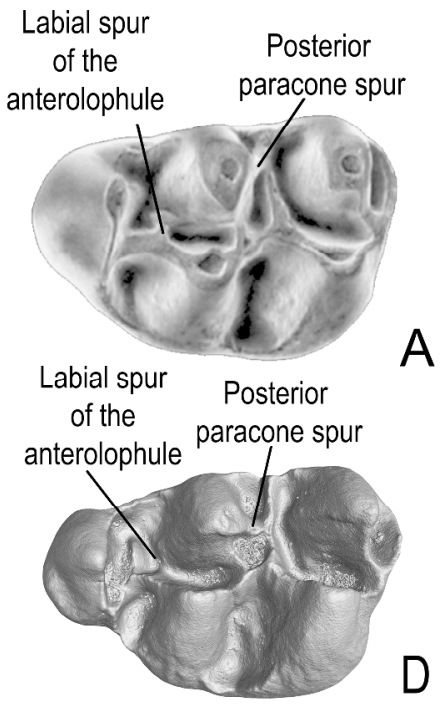

A
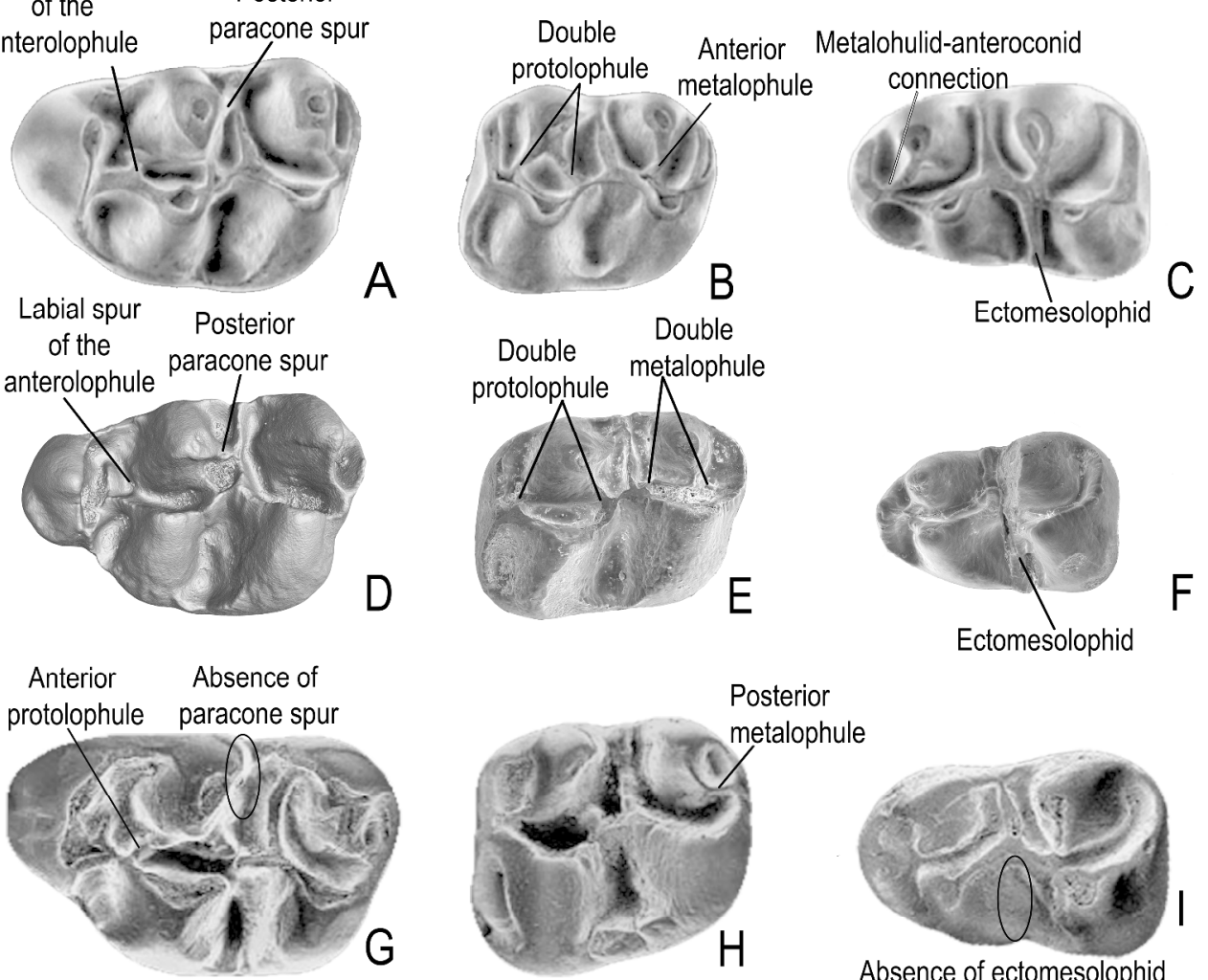

E

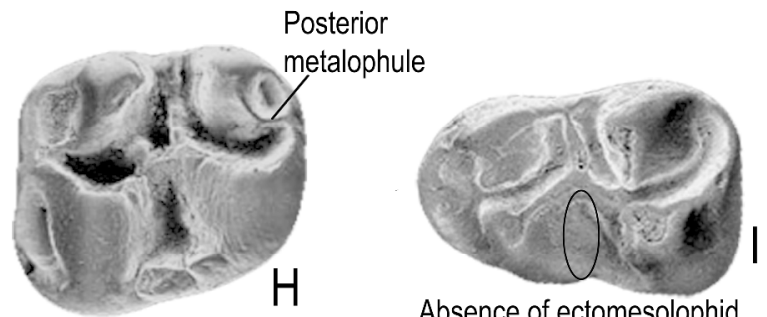

Absence of ectomesolophid

Evolutionary stage of various species of Karydomys with some important structures signaled. A-C, Karydomys dzerzhinskii (taken from Kordikova \& de Bruijn, 2001); D-F, Karydomys strati sp. nov.; G-I, Karydomys wigharti (taken from Mörs \& Kalthoff, 2004). The scale is not included as the morphology only is considered. 


\begin{tabular}{|l|l|l|l|l|}
\hline & & & Length & Width \\
\hline Karydomys strati & Thy 0-39 & $\mathrm{m} 1$ & 1.79 & 1.224 \\
\hline Karydomys strati & Thy 0-2 & $\mathrm{m} 2$ & 1.667 & 1.385 \\
\hline Karydomys strati & Thy 0-5 & $\mathrm{m} 2$ & 1.865 & 1.513 \\
\hline Karydomys strati & Thy 0-145 & $\mathrm{m} 3$ (broken) & $/$ & $/$ \\
\hline Karydomys strati & Thy 0-9 & $\mathrm{M} 1$ & 2.398 & 1.477 \\
\hline Karydomys strati & Thy 0-30 & $\mathrm{M} 2$ & 1.857 & 1.372 \\
\hline Karydomys strati & Thy 0-48 & M2 (eroded) & 1.527 & 1.316 \\
\hline Karydomys strati & Thy 0-54 & M2 (broken) & $/$ & $/$ \\
\hline
\end{tabular}




\section{Appendix S1}

Character list used in this analysis

1-Size: (0) small, 1.2-1.8 mm; (1) medium size, 1.8-2.6 mm; (2) large $>2.6 \mathrm{~mm}$

2-Cusps: (0) slender; (1) stout

M1

3-Anterocone (0) single; (1) slightly divided or crest like; (2) divided

4-Anterolabial cingulum (0)present; (1)absent

5-Labial spur of the anterocone: (0) absent; (1) present

6-Labial spur on the anterolophule: (0) absent; (1) present

7-Anterior Protolophule: (0) absent; (1) present

8-Backward paracone spur: (0) very weak or absent; (1) short but distinct; (2) long

9-Mesoloph: (0) long; (1) short or medium length; (2) absent

10-Metalophule: (0) anterior; (1) posterior

11-Posteroloph: (0) long; (1) continues beyond the metalophule; (2) does not continue beyond the metaloph; (3) absent

12- Roots: (0) 3; (1) 4

M2

13-Anterior Protolophule: (0) complete; (1) weak; (2) absent

14-Posterior Protolophule: (0) absent; (1) weak; (2) complete

15-Backward paracone spur: (0) absent; (1) present

16-Mesoloph: (0) long; (1) short or medium sized; (2) absent

17-Metaloph: (0) anterior; (1) double; (2) posterior

18-Roots: (0) three; (1) four

M3 
19-Relative size: (0) large, LM1/LM3 <1.7; (1) small, LM1/LM3 >1.7

20-Neoentoloph: (0) absent; (1) present

21-Mesoloph: (0) absent; (1) short; (2) long

$\mathrm{m} 1$

22-Anteroconid: (0) small; (1) large

23-Lingual anterolophid: (0) well-developed; (1) short (2) absent

24-Metalophulid anterior: (0) absent; (1) connected to the anterolophid (2) connected to the anteroconid

25-Metalophulid posterior: (0) present; (1) mostly absent

26-m1-Mesolophid (0) absent; (1) short to medium lenght (lenght $<1 / 3$ of the distance between ectolophid and lingual border); (2) long to medium length

27-Ectomesolophid: (0) very weak or absent; (1) present

$\mathrm{m} 2$

28-Lingual anterolophid: (0) developed; (1) very weak or not developed

29-Posterior metalophulid: (0) present; (1) weak or absent

30-Mesolophid: (0) short (lenght $<1 / 3$ of the distance between ectolophid and lingual border); (1) long

$\mathrm{m} 3$

31-Protosinusid: (0) retracted and directed forward; (1) circular

32-Mesolophid: (0) present; (1) absent 